\title{
The Ethical Necessities and Principles in Telerehabilitation
}

\author{
Telerehabilitasyonda Etik Gereklilikler ve İlkeler
}

\author{
Fatih ÖZDEN ${ }^{1}$ (D), Yassine LEMBARKI' (iD)
}

\section{ÖZ}

Teknolojik gelişmelerin artmasıyla birlikte sağlık hizmetlerinde teknolojik uygulamaların kullanımı artmıştır. Rehabilitasyon kapsaminda hizmetlerinde kullanılan teknolojik uygulamaların başında telerehabilitasyon gelmektedir. Telerehabilitasyon uygulamalarının etik prensipler çerçevesinde uygulanması hasta mahremiyetinin korunması adına büyük önem taşımaktadır. Telerehabilitasyon etiği hususunda uluslararası standartlardaki eksiklik ve uygulanabilecek yasal hükümlerin bulunmaması, pratikte bu uygulamaların kullanımının ve etkili bir şekilde yaygınlaşmasının önündeki en büyük engellerden biridir. Maliyet, zaman ve kullanım kolaylığı sağlayan bu uygulamaların kullanımının olumsuz sonuçlar ortaya koymasını önlemek adına etik prensiplerin net bir şekilde ortaya koyulması ve yasalarla birlikte ele alınması gereklidir. $\mathrm{Bu}$ derlemede telerehabilitasyon uygulamalarında dikkate alınması gereken etik prensipler ele alınmış ve olası kural ihlallerinin nasıl sonuçlar doğurabileceği incelenmiştir.

Anahtar Kelimeler: Telerehabilitasyon, Etik, Rehabilitasyon

\section{ABSTRACT}

With the increase in technological developments, the use of technological applications in health services has increased. Telerehabilitation is one of the technological applications used in rehabilitation services. The application of telerehabilitation practices within the framework of ethical principles is of great importance for the protection of patient privacy. The lack of international standards on the ethics of telerehabilitation and the lack of applicable legal provisions is one of the major obstacles to the effective use and widespread use of these practices. In order to prevent the use of these practices that provide cost, time and ease of use to produce negative results, ethical principles should be clearly defined and handled with the laws. In this review, ethical principles that should be taken into consideration in telerehabilitation applications are discussed and how possible violations of rules can have consequences.

Keywords: Telerehabilitation, Ethics, Rehabilitation

Fatih ÖZDEN (ه)

${ }^{1}$ Muğla Sitkı Koçman University, Department of Elderly Care, Köyceğiz Vocational School of Health Services

e-mail:fatihozden@mu.edu.tr

Yassine LEMBARKI

${ }^{2}$ Adnan Menderes University, Institute of Health Sciences, Department of Anatomy

\section{INTRODUCTION}

\section{Basic concepts and the necessity of ethical rules in telerehabilitation}

Between the bloodletting techniques of the 18th century and now days robot-assisted surgery that allows surgeons to perform many types of complex procedures with more precision and from hundreds of miles of distance, medicine practice has advanced significantly (1). In the last decade, technology and telehealth in particular, has become increasingly used in global health service delivery $(2,3)$. Telehealth is a board term that describes the use and promotion of electronic or digital information and communications technologies to support clinical healthcare, education and public health (4). Telehealth services does not only rely on traditional video conferencing, at the same time e-mail, remote patient monitoring devices and even facsimile (5). Tele-rehabilitation is a specific reference to the providing of rehabilitation and habilitation services through information and communication technologies (ICT), often referred to as 'tele-health' technologies. Telerehabilitation services include assessment, monitoring, prevention, intervention, supervision, training, counselling and coaching. Tele-rehabilitation services can be provided to all patient populations and multiple healthcare settings, including clinics, homes, schools or community-based construction sites. Lack of international standards and the absence of legal provisions applicable to remote services have been identified as one of the major obstacles to the effective spread of telehealth in daily practice (6). The most important issue in telehealth might be ethics for which there are thousands of definitions. As telehealth develops, new ethical and legal questions are emerging. The former "New York Time" ethicist Randy Cohn (2002) defines it as a respond to the question "how should I act now?" also adding that ethics is not just knowing but doing. It is our understanding that beside the state licensures, tele-practice 
ethics rely mostly on the clinician's sensitivity in protecting patient privacy (7).

\section{Literature Review}

\section{a. Ethics in electronic medical record systems}

Rapid technological developments in recent years have led to the spread of electronic medical record (EMR) systems. Critical improvements have been made in terms of efficiency on quality basis, beside the improvement of patient information security and cost control in medical care services provided to patients through electronic medical record systems. Advantages of EMR for patients; better and faster sharing of patient data between and within the institution, access to the data when necessary, better protection of the data and increasing the percentage of accuracy, resulting in better medical decision-making and prevention of adverse drug reactions. In addition, records related to billing and payment and health costs are monitored in a more controlled manner $(8,9)$. In addition to these advantages, EMR has disadvantages for patients. In order to avoid these disadvantages, some ethical principles and protected situations need to be observed. One of these problems is the potential hazards of copying and pasting data from other clinicians for any purpose. The accuracy or up-to-datedness of the copied information, as well as the unauthorized transfer of personal data to different databases, and therefore the protection of personal data In addition, confusion may occur due to the uncertainty of the authors of the clinical information contained in some EMRs and the failure to enter these data at the required time. One of the most common ethical problems is the template data provided by the software to facilitate the work of clinicians. These templates are filled in and recorded with patient-specific information. Failure to use these templates appropriately results in inaccurate recordings of patient assessments into the system. These similar shortcuts provided by the software are the features that clinicians should use with care (10-12). When it is considered in terms of social relations, visiting the patient's room of the clinician, instead of filling the notebook in the patient's room, filling the necessary information from the computer on the patient's page can sometimes damage the patient clinician's communication (13-15). One of the most common ethical pronouns is that EMRs are used for billing and storage of evidence data to health insurers rather than the ability to record and store patient documents. The efficiency of EMRs is reduced due to the use of only billing parts of the software, the use of pathology codes for pricing purposes only, and other similar purposes (12). Proper management of technical details, such as intrusive attacks, antivirus applications, firewalls, and software updates, is important for the proper protection of patient data (16).

\section{b. Ethics in Patient Monitoring Applications}

'E-health' applications, which include video conferencing technologies, mobile or web applications and internet-based training platforms, are becoming more and more widespread as an effective communication tool for consultation and second opinion between patients and health professionals as well as for health professionals (17). Some of the concepts for the protection of ethical elements of patients in web and mobile applications developed for remote evaluation and treatment of patients in telerehabilitation are presented below (18).

Privacy and Security: Protection of patient privacy and confidentiality arising from the use of telerehabilitation systems software is one of the most important ethical principles. Necessary precautions should be taken against the risk of improper disclosure of information from these databases containing the patient's personal data. In order to protect the confidentiality of patient information, user agreements should be determined within the framework of legal and ethical regulations (19).

Informed Consent: With the widespread use of technology, possible ethical violations that may occur should be overcome by electronic consent forms to be presented to patients. Patients should be signed an informed consent form that presents legal policies, confidentiality issues and potential risk situations, the advantages and possible disadvantages of telerehabilitation related to the use of software technologies (20).

Hacking and Third-Party Data Ownership and Identity Verification: The security of data collected through telerehabilitation is never guaranteed. Medical data generated by hackers and third-party applications leads to significant financial losses. In order to protect this, authentication systems such as "two factor authentication" have been developed. Even with modern encryption methods, this data cannot be protected at the desired level (21). 
Patient Access to Telerehabilitation: Although internet infrastructure and electronic communication devices have increased in recent years, it may not be sufficient in relation to socio-economic level in some parts of the population, especially in rural areas. Even if the facilities are sufficient, the potential infrastructure required to transmit large amounts of data to the patient population in this group may not be appropriate. There is an ethical obligation not to prevent these patients from taking advantage of mHealth (22).

\section{CONCLUSION}

Today, with the rapidly developing information technologies, the protection of the privacy of digital data has become so sensitive. In order to protect the data circulating in the digital environment, clinicians should take care individually. In addition, it is important that telerehabilitation systems should have specific features in accordance with ethical principles. Patient data should be used with the consent of the patient. It is a well-known fact that telerehabilitation provides cost and time savings as well as convenience for clinicians. however, health professionals should not abuse this situation and use the systems in accordance with ethical principles. It is concluded from this review that personal data protection, software security and patient consent are the three most important parameters for telerehabilitation ethics.

\section{REFERENCES}

1. R. Eveleth. The Surgeon Who Operates From 400 km Away. Web Page [Date of access: 6 November 2019]

2. Holt B, Faraklas I, Theurer L, Cochran A, Saffle JR. Telemedicine use among burn centers in the United States: a survey. Journal of burn care \& research. 2012;33(1):157-62.

3. Wilson LS, Maeder AJ. Recent directions in telemedicine: review of trends in research and practice. Healthcare informatics research. 2015;21(4):213-22.

4. Moffatt JJ, Eley DS. The reported benefits of telehealth for rural Australians. Australian Health Review. 2010;34(3):27681.

5. Majerowicz A, Tracy S. Telemedicine: Bridging gaps in healthcare delivery. Journal of AHIMA. 2010;81(5):52-3.

6. Brennan D, Tindall L, Theodoros D, Brown J, Campbell M, Christiana D, Smith D, Cason J, Lee. A blueprint for telerehabilitation guidelines. International journal of telerehabilitation. 2010;2(2):31.

7. Cohn ER. Tele-ethics in telepractice for communication disorders. Perspectives on Telepractice. 2012;2(1):3-15.

8. Clifford GD, Blaya JA, Hall-Clifford R, Fraser HSF. Medical information systems: A foundation for healthcare technologies in developing countries. BioMed Central. 2008; 7(18):1-8.

9. Busis NA. How can I choose the best electronic health record system for my practice? Neurology. 2010;75(18 Supplement 1):60-4.

10. Hammond KW, Helbig ST, Benson CC, Brathwaite-Sketoe BM. Are elec - tronic records trustworthy? Observations on copying, pasting and dupli - cation. AMIA Annu Symp Proc 2003;269-73.

11. Menachemi N, Collum TH. Benefits and drawbacks of electronic health record systems. Risk management and healthcare policy. 2011;4:47.

12. Bernat JL. Ethical and quality pitfalls in electronic health records. Neurology. 2013;80(11):1057-61.

13. O'Malley AS, Cohen GR, Grossman JM. Electronic medical records and communication with patients and other clinicians: are we talking less? Issue Brief Cent Stud Health Syst Change. 2010;(131):1-4.

14. Shachak A, Reis S. The impact of electronic medical records on patient-doctor communication during consultation: a narrative literature review. Journal of evaluation in clinical practice. 2009;15(4):641-9.

15. Balka E, Tolar M. Everyday ethical dilemmas arising with electronic record use in primary care. Studies in health technology and informatics. 2011;169:285-9.

16. Chiuchisan I, Balan DG, Geman O, Chiuchisan I, Gordin I. A security approach for health care information systems. E-Health and Bioengineering Conference, IEEE, 2017; 21724.

17. George C, Whitehouse D, Duquenoy P. eHealth: legal, ethical and governance challenges. Springer Science \& Business Media. 2012.

18. Holmes CM, Reid CA. Ethics in Telerehabilitation: Looking Ahead. Journal of Applied Rehabilitation Counseling. 2018;49(2):14-23.

19. Stanberry B. Legal ethical and risk issues in telemedicine. Computer methods and programs in biomedicine. 2001;64(3):225-33.

20. Recupero PR, Rainey SE. Informed consent to e-therapy. American journal of psychotherapy. 2005;59(4):319-31.

21. He D, Naveed M, Gunter CA, Nahrstedt K, editors. Security concerns in Android mHealth apps. American Medical Informatics Association. 2014;645.

22. Carter A, Liddle J, Hall W, Chenery H. Mobile phones in research and treatment: ethical guidelines and future directions. JMIR mHealth and uHealth. 2015;3(4):e95. 